\title{
The Nexus Between Agriculture and Tourism in the Island of Crete, Greece
}

\begin{abstract}
John Vourdoubas
Mediterranean Agronomic Institute of Chania, 73100, Chania, Crete, Greece. Tel: +30-28210-35020, E-mail: vourdoubas@chania.teicrete.gr
\end{abstract}

Received: Jan. 20, 2020

doi:10.5296/jas.v8i2.16602
Accepted: Feb. 26, $2020 \quad$ Published: Mar. 4, 2020

URL: https://doi.org/10.5296/jas.v8i2.16602

\begin{abstract}
The relationship between agriculture and tourism in the island of Crete, Greece has been studied. Both agriculture and the tourism industry contribute more than 50\% in the Gross Domestic Product of the island. The linkages between agriculture and tourism in many tourism-dominated communities and rural areas worldwide have been reviewed. The current status of agriculture and the tourism industry in Crete has been examined as well as the agro-tourism development in the island during the last few decades which is considered a typical example of agriculture-tourism cooperation. The healthy tasty Cretan diet is based on locally produced food ingredients and it is famous all over the world. Therefore, it could be further promoted by the tourism industry in the island. Increased use of local gastronomy could improve the competitiveness of the Cretan tourism industry which is currently based on mass tourism and the "sea, sun and sand" model. This could be a springboard to the local agricultural production of the island to partly cover the demand for catering in the tourism industry. Various new policies and measures are required for increasing the linkages in these two sectors. The use of locally produced agricultural products would replace foodstuff transported to the island from long distances, reducing the carbon emissions due to their transportation. Strengthening the linkages between agriculture and tourism in Crete would trigger growth in both sectors, offering many economic, social and environmental benefits to the island.
\end{abstract}

Keywords: Agriculture, agro-tourism, Crete, Greece, food, linkages, rural, tourism industry

\section{Introduction}

The tourism industry is currently well developed in the island of Crete, Greece while the mild climate of the island favors the production of many agricultural food products. Both tourism and agriculture are very important for the island's economy, contributing more than $50 \%$ of the regional gross domestic product in Crete. These two sectors are already linked, since visitors require food partly provided by local farms, while their increased relationship in the 
future is desirable and feasible. It would result in many economic, social and environmental benefits to the island. Agro-tourism has already been financially supported and promoted in Crete, resulting in the development of tourism accommodation in remote and rural communities, while tourists have the opportunity to taste delicious food products already produced in the host farms. Researchers all over the world have already emphasized the various benefits resulting in the symbiosis of the tourism industry with agriculture in many tourism-dominated and rural territories, both in developing and developed countries. An investigation of the current and future linkages of the tourism industry and agriculture in Crete, Greece could help increase the existing relationships and improve networking among various stakeholders of these two important sectors in the local economy.

\section{Literature Survey}

\subsection{Agriculture and Tourism Linkages}

Torres, 2002 has investigated the linkages between tourism and agriculture in the Yucatan, Mexico. The author stated that tourists' food consumption and preferences do not represent a major obstacle in promoting future tourism and agricultural linkages. She suggested the creation of a "strategic alliance" among hotels, restaurants, food producers and whole sellers to "educate" tourists in order to promote production and consumption of locally grown products. Torres, 2003 also studied the linkages between tourism and agriculture in Mexico. The author mentioned that tourism and agriculture linkages in Quintana, Roo, Mexico are weak due to several constraining factors. She concluded that enhancing tourism and agricultural linkages will stimulate local production, retain tourism earnings in the region and distribute tourism benefits to local people. Torres et al, 2004 studied the challenges and potential for linking tourism and agriculture in Mexico. The authors stated that hotel chefs and farmers who supply the tourism industry should increase their cooperation for achieving pro-poor tourism objectives. They concluded that developing linkages between tourists' food consumption and local agricultural production represents an important mechanism for achieving pro-poor tourism objectives. Timms, 2006 has reported on Caribbean agriculture-tourism linkages. The author stated that if the demand for agricultural products is increased due to the development in other sectors of the economy, then the farmers would be in a better position. He suggested that the linkages between hotels and farmers should be strengthened in the Caribbean region in order to increase local agricultural production and farmers' income. Berno, 2011 has studied the linkages between agriculture and food in the Fiji islands' tourism industry. The author mentioned that better linkages between these two sectors not only result in higher levels of economic growth but they can also contribute significantly to the ethos of sustainable tourism. For Fiji, she identified seven different mechanisms that supported agriculture-tourism linkages which could be used in other countries as well. Mshenga, 2010 has investigated the tourism and agricultural linkages on the Kenyan coast. The author found that various local agricultural products were purchased by the hotels. She concluded that local farmers should orient their production according to the requirements of the local tourism industry, by providing the hotels with foodstuff in the desired quality and quantity. Green et al, 2008 have studied the impacts of culinary tourism in the development strategy of a community. The authors stated that the establishment of local 
markets for farmers requires community effort to coordinate supply and demand. They also mentioned that culinary tourism offers new opportunities for communities to integrate tourism and local food systems in order to promote their economic development. Scheyvens, 2016 has investigated the tourism-poverty nexus. The author mentioned that pro-poor tourism is related with the distribution of benefits from tourism in favor of poor people. She also stated that one core activity of pro-poor tourism is related with supplying local enterprises with locally produced food and sensitizing tourists to buy local foodstuff. Rogerson, 2012 has reported on strengthening agriculture-tourism linkages in the developing world. The author mentioned that building linkages between agriculture and tourism is critical for maximizing tourism's economic impact in developing countries. She stated that the building of trust between tourism and agriculture stakeholders is considered an essential foundation for evolving sustainable linkages between tourism and agriculture sectors. A report on agriculture and tourism linkages in Pacific island countries has been released by FAO, UN, 2012. The report mentioned that the nexus between agriculture, tourism and environment is crucial for policy development. It suggested that "environmentally friendly" agriculture could help in the environmental sustainability of the region. Promotion of organic agriculture will provide synergies with the tourism industry, increasing the demand in local agricultural products. Tefler et al, 1996 have investigated the linkages between tourism and food production. The authors mentioned that the relationship between food production and tourism range from conflict over competition for land, labor and capital, to symbiosis where both sectors mutually benefit from each other. They also stated that there is potential to increase linkages between tourism and local food production but there are various challenges to be overcome in doing so. Cox et al, 1995 have investigated the impacts of tourism on agriculture in Hawaii. The authors stated that the tourism industry changed the structure of Hawaii's agriculture without destroying it. They found that tourists acquired new tastes during their vacations, eating local foodstuff and assisting in the growth of local agriculture. Mei et al, 2016 have studied the collaboration between tourism and agriculture in Norway. The authors stated that building relationships and sharing knowledge between tourist enterprises and foodstuff producers remains difficult. However, they concluded, there are various opportunities for cooperation between agriculture and the tourism industry in Norway. Forsyth, 1995 has studied the development of agriculture and tourism in a village in Northern Thailand. The author found that tourism in the village was adopted by those with available cash and labor while it was unavailable to the poorest small landowners who were seeking a new source of income. Knowd, 2006 has investigated the linkages among tourism, agriculture and local development in the peri-urban zones of Sydney, Australia. The author emphasized the new relations which were established among farmers, tourism stakeholders and the local economy and society. He mentioned that an increased interconnectedness was created with positive impacts in the region. Jimenez-Beltran et al, 2016 have studied the relationship between tourism and food culture focused on the city of Cordoba, Spain. The authors mentioned that tourists were categorized in three groups including healthy-cultural tourists, cultural tourists and generic tourists. They also stated that the local gastronomy and its healthy identity were important for tourists' satisfaction. Langworthy et al, 2006 implemented a project related to increasing the linkage between tourism and agriculture, focused on Victoria, Australia. The 
authors mentioned that although the two sectors had much to gain from close cooperation, they do not always communicate and cooperate effectively. Their recommendations include: a) Facilitation of the cooperation between agriculture and tourism, b) Encouragement of entrepreneurial development between the two sectors, and c) Improvement of the infrastructure in the region.

\subsection{Agro-tourism}

Privitera, 2010 has investigated the importance of organic agriculture in rural tourism with reference to an area in south Italy. The author stated that the demand for healthy food and organic agriculture has been spring boarded with agro-tourism. She concluded that some farms in rural communities in Sicily, Italy offering tourism services should be focused on organic agriculture. This would result in offering healthy products to their visitors, increasing the farm's income both from agricultural and tourism activities. Karakuzulu, 2007 has investigated the relationship between ecological agriculture and tourism in Turkey. The author mentioned that in this country, in 2007, there were nearly 70 ecological farms accepting tourists, located mainly in Mediterranean region. She proposed that ecological agricultural tourism offers an integrated approach in local development and the concept of "Ecological agricultural tourism" should be promoted in the future. Fleischer et al, 2005 studied the impacts of agriculture on rural tourism in Israel. The authors found that a farm offering accommodation to tourists does not benefit from tourism services. However, it uses its production factors more efficiently in producing foodstuff and services, achieving various benefits compared with a single farm. Richardson-Ngwenya et al, 2011 have investigated the relations between tourism and agriculture in the Barbados islands. The authors stated that in these islands tourism is replacing agriculture as the main driving force of the economy. The government is trying to increase economic development in these islands by the promotion of "agro-tourism linkages" which have multiple benefits to both sectors. Choenkwan et al, 2016 have reported on the impacts of agro-tourism to mountain farmers. The authors mentioned that the relationship between agriculture and tourism is complex and the extent to which tourism benefits farmers remains uncertain. They concluded that many local farmers, in the Phu Ruea district, Northeast Thailand, derived significant benefits from their involvement in the agro-tourism system.

\subsection{The Carbon Footprint in Food Transportation}

Garnett et al, 2016 have studied the GHG emissions in various food systems. The authors mentioned that the food system contributes $20-30 \%$ of global GHG emissions. They also stated that emissions depend on the mode of transport while localized food systems have various social and environmental benefits. Food transport in USA results in $11 \%$ of food-related GHG emissions. Konieczny et al, 2013 have studied the use of carbon footprints to evaluate the environmental issues of food transportation. The authors stated that food commodities are transported often over long distances to reach the desired markets. They suggested that the carbon footprint during their transportation should be taken into account from an environmental point of view together with quality and safety considerations. Wakeland et al, 2012 have studied the carbon footprint due to food transportation. The 
authors mentioned that foodstuff is often shipped over long distances, frequently via air, resulting in high GHG emissions. They also stated that the transportation-related carbon footprint of food varies from a low percentage to more than half of the total carbon footprinst associated with food production, distribution and storage. Gossling et al, 2011 have studied the reduction of carbon emissions due to food consumption by tourists. The authors mentioned that some foodstuffs have higher GHG emissions than others. Their better management could reduce the carbon footprint in the tourism industry. However, they stated that the complexity of food production chains and the limited existing data on the carbon intensity of various foodstuff hampers their optimum and environmental use in the tourism industry.

\subsection{Tourism Industry in Crete}

Smart Specialization Strategy of Crete, 2015 has prioritized four economic activities in order to improve the region's global competitiveness. These four priorities include: a) The agro-alimentary complex, b) The cultural-touristic complex, c) The environmental complex, and d) The knowledge complex. The tourism industry and the agro-food sector are two pillars of the Cretan economy which could be further linked and developed in the island. Vourdoubas, 2019 has estimated carbon emissions due to the tourism industry in Crete, Greece. The author mentioned that the estimated carbon emissions per trip due to tourism in Crete are higher than the average global value reported. He also stated that approximately $80 \%$ of the total tourism-related carbon emissions are due to tourist transportation to and from the island and the rest to accommodation and other tourist activities. Vourdoubas, 2020 has investigated the carbon intensity of the tourism industry in Crete. The author estimated that the carbon intensity of this industry is in the same range of values reported in other tourist territories. He also mentioned that foodstuff imported in Crete by air transportation and used by the tourists increased its carbon intensity due to high emissions of air transport.

The aims of the current study are:

a) To investigate the relations between agriculture and tourism in various tourism-dominated and rural territories,

b) To examine the current status of agriculture and tourism in Crete and their linkages, and

c) To propose policy measures which could strengthen the linkages between agriculture and tourism in Crete, Greece.

The methodology followed includes an investigation of tourism and agriculture in various territories, the agricultural sector in Crete, the development of the agro-tourism sector in the island, and finally, recommendations of various policy measures for increasing the linkages between these two important sectors of the local economy. Although there are enough data regarding the annual visitors to the island, there is limited information regarding the variety and quantity of foodstuff needed for feeding tourists in Crete, as well as the amount of food which is imported, which is needed for catering to tourists. 


\subsection{Tourism industry in Crete}

Crete is the second largest island in the Eastern Mediterranean sea after Cyprus and the fifth in size in the Mediterranean basin. Its area is $8332 \mathrm{Km}^{2}$ and its population according to the recent census was 621340 inhabitants. The island has three international airports and six sea ports which are used for tourist arrivals and departures. Crete has many attractions and beauty spots, satisfying the preferences of different tourist categories. There are charming landscapes and gorges, high mountains, long coastlines and unique sandy beaches. There are also various well preserved antiquities as well as religious monuments, reminding one the presence and the glory of previous civilizations. Tourists enjoy the mild climate and the natural beauties of the island, combined with visits to various historical and cultural sites and attractions. One valuable asset of the island's tourism industry is the famous and healthy local gastronomy. Crete is very popular and well known globally among travelers as a desirable tourist destination. Annual visitors in the island, during the last years, exceeded 5 mil., while most of them are coming during the period from April to October each year, while during the winter period the summer resorts remain closed. The tourism industry in the island had developed rapidly after the 1970s, following the model of industrial tourism, prioritizing the attractions of sea, sun and sand. However other types of thematic tourism are also promoted, differentiating the local touristic product. Currently the tourism industry is very important for the Cretan economy and its share in the regional GDP is estimated at $47 \%$. Employment in this industry is increasing, attracting young people and counterbalancing the decrease of employment in agriculture, which was traditionally the main driver in the regional economy and employment.

\subsection{Agriculture in Crete}

Agriculture is very important for the Cretan economy although its contribution in the regional GDP is relatively low at $7.5 \%$ in 2008 (Investment profile of Crete, 2011). The mild climate in the island is supporting the production of a variety of excellent quality agricultural products. A few decades ago, agriculture was the main driving force in the Cretan economy, creating job opportunities and wealth to local inhabitants. However, later, the development of the tourism industry has replaced agriculture as the most important sector in the local economy. Foods and beverages consist of $56 \%$ of the total annual exports from the island including olive oil, wine, citrus fruits, bakery goods, raisins, herbs, honey etc. Annual olive oil production in Crete varies between 100 000-150 000 tons while its excellent quality is globally well known. Wine is also produced in the island and its annual production is estimated at 750000 hectoliters. Dairy products are important for the local economy, and they are well known outside of Crete, produced from goat's and sheep's milk. Almost half of the existing agricultural greenhouses of Greece are located in Crete due to its mild climate which favors production of various vegetables. They produce off-season tomatoes, cucumbers, peppers and eggplants, which are consumed either in Crete from locals and tourists, or they are transported in large consumption centers. The main agro-food products produced in Crete are presented in Table 1. 
Table 1. Main agro-food products currently produced in Crete, Greece

Various vegetables including tomatoes, cucumbers, peppers, eggplants, green vegetables, onions etc

Various fruits including oranges, lemons, grapes, mandarins, pears, grapefruits, kiwi, peaches, potatoes, figs etc

Honey

Various endemic aromatic herbs

Wine

Olives, Olive oil, Avocado

Milk and dairy products including various types of cheese, yogurt etc

Raisins

Meat produced mainly from sheep, goats and chickens bred locally

Beverages

Bakery products

\subsection{Tourist catering in Crete}

In order to feed tourists in the island of Crete, large quantities of foodstuff are needed. Currently the food production system in the island can't alone produce the foodstuff needed annually in the tourism industry, but only part of it. Therefore, food and beverages are imported in Crete by air and sea. This results in an increase in the carbon intensity of the local tourism industry. However, the local food production system, assisted by the mild climate conditions in the island, could be oriented in covering part of the needs of the tourism industry. Various vegetables could be produced locally instead of being imported from other territories. This presupposes that the food production costs in Crete will be competitive with the cost of the imported foodstuff. The orientation of the agriculture sector in Crete towards producing foodstuff which is consumed by the visitors in the island would reduce the carbon emissions of the local tourism industry. The Cretan tourism industry must be very competitive in order to attract international tourists. Since the majority of tourists are looking for cheap destinations to spend their holidays, they prefer "all inclusive" hotels offering both accommodation and catering because they are cheaper. These Cretan hotels are trying to minimize their costs in buying cheap foodstuff which is usually imported in Crete. Other hotels are hosting visitors who are willing to pay more for accommodation and catering. 
These hotels are offering local traditional dishes which are usually more expensive. Therefore both cheap as well as more expensive and high quality food products are demanded by the local tourism industry.

\subsection{The famous Cretan Diet and Gastronomy}

The Cretan diet is famous all over the world due to its healthy impacts. It is based on a high consumption of local vegetables, green herbs, fruits and olive oil, moderate consumption of cheese, fish and red wine and low consumption of eggs, milk and meat. These ingredients contain fibers, healthy fatty acids, antioxidants, various vitamins, etc. which result, when consumed, in a long and healthy life. It has been indicated from various extensive medical studies that the dietary pattern of Crete results in low cancer and heart-related diseases (Simopoulos, 2001). Additionally Cretan dishes and gastronomy are delicious and known worldwide, while tourists spending their vacations on the island consider tasting the local cuisine as a must, wishing to taste the various recipes offered. Most of the food ingredients used in local dishes are produced in Crete, supporting the local agriculture. Cretan gastronomy is considered as a valuable local asset which increases the competitiveness of the island's tourism industry.

\subsection{Agro-tourism in Crete}

Agro-tourism has been developed during the last two-three decades in Crete due to the necessity of farmers to create additional incomes since their incomes from traditional agricultural activities were not sufficient to maintain their prosperity. Agro-tourism offers an alternative activity in rural areas which could help farmers to increase their incomes and avoid migration, sustaining their agricultural activities and contributing to the environmental protection of their territories. It was financially supported by the EU and the Greek government. Implemented studies so far have indicated that agro-tourism in Crete is limited to accommodation services without promoting active tourist involvement in farm activities (Alexakis, 2014). Evidence regarding the contribution of agro-tourism in the promotion of the local culture, traditions and architecture has not been found in Crete. Agro-tourism offers the opportunity to visitors to taste the traditional local food prepared in their accommodation by the owners and take part in a genuine experience of the famous, delicious and healthy Cretan cuisine. Proposals for combining agro-tourism with organic agriculture with the involvement of young people could offer many advantages, attracting wealthy tourists willing to spend their vacations in the countryside, combined with a healthy traditional diet (Lanterbach, 2012). It has been proposed that agro-tourism should increase its synergies with various other tourism stakeholders in Crete while it should try to attract visitors all year around instead of being seasonally oriented.

\subsection{Increasing the Links Between Tourism and Agriculture in Crete}

Increasing the relationship between agriculture and the tourism industry in the island of Crete, Greece would result in many benefits to all stakeholders involved. Private and public authorities in Crete should cooperate in order to achieve a better symbiosis among them. Individual farmers as well as farmers' associations, tour operators, hotels and other tourist 
accommodations, and wholesalers of food products should increase their linkages for mutual benefit. Public authorities should encourage cooperation providing appropriate incentives. Sensitization of tourists regarding the delicious and healthy local diet is important for the promotion of locally produced foodstuff in the hotel's restaurants. Orientation of the agricultural sector in the island towards production of foodstuff demanded by the tourists in Crete in a cost-effective way is necessary. Promotion of organic agriculture would provide foodstuff consumed by wealthy and environmentally-conscious visitors during their holidays. This requires new investments in agriculture; it will create new incomes and jobs in the primary sector of the economy and it will result in environmental benefits. The benefits due to the increase of symbiosis between agriculture and tourism in Crete are presented in Table 2. The policy measures which could strengthen the relationship between agriculture and tourism in Crete are presented in Table 3.

Table 2. Benefits of strengthening the linkages between the tourism industry and agriculture in Crete, Greece

Farmers will have a new local market for selling their agricultural products

Poor farmers will benefit more from producing foodstuff required by the local hotels and restaurants

Possibilities for developing eco-agriculture producing organic foodstuff is desirable from environmentally-conscious tourists

Production of local food products used by tourists replacing imported foodstuff will decrease the tourism-related footprint due to fewer food imports and less transportation

Development of agro-tourism will create new incomes and jobs in rural areas with limited alternative resources and opportunities for growth

Agriculture and tourism comprise two out of four major pillars for development in the region of Crete according to the recent smart specialization strategy for Crete. Strengthening their linkages would result in many synergies in those two important sectors of the local economy. 
Table 3. Policy measures which could strengthen the relationship between agriculture and tourism in Crete, Greece.

\begin{tabular}{l|l}
\hline 1 & Tourism operators buy foodstuff directly from the local markets \\
\hline 2 & Hotels establish contracts with local farmers regarding food supply \\
\hline 3 & Hotels buy surplus food products from the local markets \\
\hline 4 & Cooperative farm associations directly supply hotels with foodstuff \\
\hline 5 & Hotels create their own gardens producing foodstuff for their own needs \\
\hline 6 & $\begin{array}{l}\text { Boutique, organic or hydroponic farms supply hotels for serving a limited } \\
\text { number of clients }\end{array}$ \\
\hline 7 & $\begin{array}{l}\text { Hotels create specific menus using only local food ingredients and traditional } \\
\text { recipes }\end{array}$ \\
\hline 8 & $\begin{array}{l}\text { Information should be provided to tourists to sensitize them regarding the } \\
\text { healthy benefits of the Cretan diet }\end{array}$ \\
\hline
\end{tabular}

\section{Discussion}

Various studies implemented so far have indicated the existing linkages between agriculture and tourism in various tourist destinations worldwide. Cooperation between these two sectors results in mutual benefits and synergies while it also supports the local economy, retaining tourism earnings in the region. Increased cooperation is feasible and desirable while various existing barriers should be removed. Agro-tourism development in rural and poor areas without many alternative resources offers the opportunity for further linkages between those two sectors. However agro-tourist enterprises should promote the engagement of tourists during their stay, in farm-implemented activities, instead of offering them only accommodation and catering. Use of locally produced foodstuff replacing food usually imported from long distances results in less transport-related carbon emissions. In that case the tourism-related carbon intensity in the territory will be decreased. Various environmentally conscious tourists demand, during their vacations, locally produced organic foodstuff. This favors the development of eco-friendly organic agriculture which offers better incomes and has less environmental burden. The mild climate of Crete favors the production of many vegetables and fruits which are the basic ingredients of the healthy and delicious Cretan diet which is well known worldwide. Local gastronomy is a strong asset of the local tourism industry. Therefore, increasing the linkage between agriculture and tourism in Crete increases the competitiveness of the island's tourism product. According to the recent smart specialization strategy of Crete, agriculture and tourism are two out of the four sectors of the 
island's economy which have been prioritized and supported in order to assist the regional development. Increasing their linkages would result in many synergies and regional benefits.

\section{Conclusions}

The tourism industry and agriculture are linked worldwide in rural or tourism-dominated communities due to various benefits resulting in the local economy, society and environment. The development of agro-tourism is a good example for linking tourism with agriculture in tourism-dominated and rural territories including Crete. The island of Crete, Greece is a popular tourist destination in the Eastern Mediterranean region while its mild climate favors the cultivation of many agricultural products. Existing relations between the tourism industry and agriculture in Crete should be increased and strengthened since it will result in many benefits for all stakeholders involved in both sectors as well as in the society and the environment. The delicious and healthy Cretan diet is famous worldwide and this is an important asset for the local tourism industry. Its promotion in Cretan hotels and restaurants presupposes the strengthening of the already existing linkages between local agriculture and tourism. The development of innovative strategies and policies has been proposed which could result in many benefits to local society, the economy and the environment while they will increase the competitiveness of the Cretan tourism industry. Future research should be oriented towards defining the agricultural food products which could be produced in Crete in a cost-effective way and used in catering for tourists on the island. It should also estimate the carbon footprint, due to transportation, of the imported foodstuff currently used by the local tourism industry.

\section{References}

Alexakis, S. (2014). Agro-tourism in Crete: lost in a labyrinth? A critical analysis. Retrieved at $14 / 1 / 2020$ from

https://www.academia.edu/10810904/Agrotourism_in_Crete_lost_in_a_labyrinth._A_critical -analysis

Berno, T. (2011). Sustainability on a plate: Linking agriculture and food in the Fiji islands tourism industry. In Torres \& Momsen (eds). Tourism and agriculture: New Geographies of Consumption, Production and Rural Restructuring, Routledge.

Choenkwan, S., Promkhambut, A., Hayao, F., \& Rambo, A. T. (2016). Does agrotourism benefit mountain farmers? A case study in Phu Ruea district, Northeast, Thailand. Mountain $\begin{array}{llll}\text { Research } \quad \text { and } & \text { Development. } & \text { 162-172. }\end{array}$ https://doi.org/10.1659/MRD-JOURNAL-D-15-00111.1

Cox, L., Fox, M., \& Bowen, R. L. (1995). Does tourism destroy agriculture? Annals of Tourism Research, 22(1), 210-213. https://doi.org/10.1016/0160-7383(95)90069-1

Fleischer, A., \& Tchetchik, A. (2005). Does rural tourism benefit from agriculture? Tourism Management, 26, 493-501. https://doi.org/10.1016/j.tourman.2003.10.003

Forsyth, T. (1995). Tourism and agricultural development in Thailand. Annals of Tourism Research, 22(4), 877-900. https://doi.org/10.1016/0160-7383(95)00019-3 
Garnett, T., Smith, P., Nicholson, W., \& Finch, J. (2016). Food systems and greenhouse gas emissions (Food source: chapters). Food Climate Research Network, University of Oxford. Retrieved at $13 / 1 / 2020$ from https://foodsource.org.uk/sites/default/files/chapters/pdfs/foodsource_chapter_3.pdf

Gossling, S., Garrod, B., Aall, C., Hille, J., \& Peeters, P. (2011). Food management in tourism: Reducing tourism's carbon "food-print". Tourism Management, 32, 534-543. https://doi.org/10.1016/j.tourman.2010.04.006

Green, G. P., \& Dougherty, M. L. (2008). Localizing linkages for food and tourism: Culinary tourism as a community development strategy. Journal of the Community Development Strategy, 39(3), 148-158. https://doi.org/10.1080/15575330809489674

Jimenez-Beltran, F. J., Lopez-Guzman, T., \& Santa Cruz, F. G. (2016). Analysis of the relationship between tourism and food culture. Sustainability, 8, 418. https://doi.org/10.3390/su8050418

Karakuzulu, Z. (2007). The relationship between the ecological agriculture and tourism in Turkey. Annals of the University of Craiova, 10, 136-152.

Knowd, I. (2006). Tourism as a mechanism for farm survival. Journal of Sustainable Tourism. 14(1), 24-42. https://doi.org/10.1080/09669580608668589

Konieczny P., Dobrucka R., \& Mroczek E. (2013). Using carbon footprint to evaluate environmental issues of food transportation. LogForum. 9(1), 3-10. http://www.logforum.net/vol9/issue1/no1

Langworthy, A., Howard, J., \& Mawson, F. (2006). Building the relationship between agriculture and Tourism - Models and benefits of cooperation, Swinburne University of Technology, Australia. Retrieved at 15/1/2020 from https://researchbank.swinburne.edu.au/file/4934c21a-0019-4e3a-b05e-5e0630fcecbb/1/PDF $\% 20 \% 2871 \% 20$ pages\%29.pdf

Lanterbach, J. (2012). Analysis of the link between tourism and agriculture in Messinia, Greece, University of Rennes. Retrieved at 14/1/2020 from https://www.cvf.gr/files/3_actions/research

files/Agrotourism $\% 20 \mathrm{in} \% 20 \mathrm{a} \% 20$ context $\% 20 \mathrm{of} \% 20$ pluriactivity $\% 20 \mathrm{in} \% 20 \mathrm{rura} \% 20 \mathrm{areas} / \mathrm{su}$ mmary_agrotourism.pdf

Mei, X. Y., Lerfald, M., \& Bråtå, H. O. (2016). Networking and collaboration between tourism and agriculture: Food tourism experiences along the National Tourist Routes of Norway. Scandinavian Journal of Hospitality and Tourism, 17(1), 59-75. https://doi.org/10.1080/15022250.2016.1262514

Mshenga, P. M. (2010). Tourism and agriculture linkages: Determinants of local agricultural products purchase by hotels at the Kenyan coast, In the second RUFORUM biennial meeting 20-24 September 2010, Entebbe, Uganda.

Privitera, D. (2010). The importance of organic agriculture in tourism rural. Applied Studies 
in Agribusiness and Commerce, 4(1-2), 59-64. https://doi.org/10.19041/Apstract/2010/1-2/8

Region of Crete, Investment profile, Invest in Greece Agency, (2011). Retrieved at 14/1/2020 from https://www.enterprisegreece.gov.gr/images/public/Crete_investment_profile.pdf

Report on Agriculture and Tourism Linkages in Pacific Island Countries, FAO, UN, 2012, Retrieved at 8/1/2020 from http://www.fao.org/3/a-an476e.pdf

Richardson-Ngwenya, P., \& Momsen, J. (2011). Tourism and agriculture in Barbados: Changing relationships, In Torres and Momsen (eds), Tourism and agriculture: New Geographies of Consumption, Production and Rural Restructuring, Routledge.

Rogerson, Ch. M. (2012). Strengthening agriculture-tourism linkages in the developing world: Opportunities, barriers and current initiatives. African Journal of Agricultural Research, 74, 616-623. https://doi.org/10.5897/AJARX11.046

Scheyvens, R. (2016). Exploring the tourism-poverty nexus. Current Issues in Tourism, 10(2-3), 231-254. https://doi.org/10.2167/cit318.0

Simopoulos, A. P. (2001). The Mediterranean diets: What is so special about the diet of Greece? The Scientific evidence. The Journal of Nutrition, 131(11), 30655-30735. https://doi.org/10.1093/jn/131.11.3065S

Smart Specialization Strategy of Crete Region, Management Authority of Crete, 2015. Retrieved at 16/1/2020 from

http://www.pepkritis.gr/wp-content/uploads/2016/02/RIS-Crete-Translation-ENG.pdf

Tefler, D.J. \& Wall, G. (1996). Linkages between tourism and food production. Annals of Tourism Research, 23(3), 6354-653. https://doi.org/10.1016/0160-7383(95)00087-9

Timms, B. (2006). Caribbean agriculture-tourism linkages in a neo-liberal world. IDPR. 28(1), 35-56. https://doi.org/10.3828/idpr.28.1.2

Torres, R. (2002). Towards a better understanding of tourism and agriculture linkages in the Yucatan: Tourist food production and preferences. Tourism Geographies, 4(3), 282-306. https://doi.org/10.1080/14616680210147436

Torres, R. (2003). Linkages between tourism and agriculture in Mexico. Annals of Tourism Research, 30(3), 546-566. https://doi.org/10.1016/S0160-7383(02)00103-2

Torres, R., \& Henshall Momsem, J. (2004). Challenges and potential for linking tourism and agriculture to achieve pro-poor tourism objectives. Progress in Development Studies, 4(4), 294-318. https://doi.org/10.1191/1464993404ps092oa

Vourdoubas, J. (2019). Estimation of carbon emissions due to tourism in the island of Crete, Greece. Journal of Tourism and Hospitality Management, 7(2), 24-32. https://doi.org/10.15640/jthm.v7n2a3

Vourdoubas, J. (2020). The tourism industry in the island of Crete, Greece: Is it carbon intensive? Sustainability in Environment, 5(1), 23-36. https://doi.org/10.22158/se.v5n1p23 


\section{Macrothink}

Journal of Agricultural Studies

ISSN 2166-0379 2020, Vol. 8, No. 2

Wakeland W., Cholette S., \& Venkat K. (2012). Food transportation issues and reducing carbon footprint. In: Boye J., Arcand Y. (eds) Green Technologies in Food Production and Processing. Food Engineering Series. Springer, Boston, MA. https://doi.org/10.1007/978-1-4614-1587-9_9

\section{Copyright Disclaimer}

Copyright for this article is retained by the author(s), with first publication rights granted to the journal.

This is an open-access article distributed under the terms and conditions of the Creative Commons Attribution license (http://creativecommons.org/licenses/by/4.0/). 